\title{
Assemblages of fish larvae and mesozooplankton across the continental shelf and shelf slope of the Andaman Sea (NE Indian Ocean)
}

\author{
Peter Munk ${ }^{1, *}$, Peter Koefoed Bjørnsen ${ }^{2}$, Pensri Boonruang $^{3}$, Michael Fryd $^{2}$, \\ Per Juel Hansen ${ }^{4}$, Vudhichai Janekarn ${ }^{3}$, Vitthaya Limtrakulvong ${ }^{3}$, Torkel Gissel \\ Nielsen ${ }^{2}$, Ole Schou Hansen ${ }^{2}$, Suree Satapoomin ${ }^{3}$, Suchat Sawangarreruks ${ }^{3}$, \\ Helge Abilhauge Thomsen ${ }^{1}$, Jette Buch Østergaard ${ }^{5}$ \\ ${ }^{1}$ Department of Marine Ecology and Aquaculture, Danish Institute for Fisheries Research, Charlottenlund Castle, \\ 2920 Charlottenlund, Denmark \\ ${ }^{2}$ Department of Marine Ecology, National Environmental Research Institute, Frederiksborgvej 399, PO Box 358, \\ 4000 Roskilde, Denmark \\ ${ }^{3}$ Phuket Marine Biological Center, PO Box 60, 83000 Phuket, Thailand \\ ${ }^{4}$ Marine Biological Laboratory, University of Copenhagen, Strandpromenaden 5, 3000 Helsingør, Denmark \\ ${ }^{5}$ Botanical Institute, University of Copenhagen, Øster Farimagsgade 2D, 1353 Copenhagen, Denmark
}

\begin{abstract}
We studied the cross-shelf variation in hydrography and plankton dynamics off west Thailand, focusing on physical-biological linkages. The overall research programme investigated linkages between physics, chemistry and plankton biology; in the present paper we consider the findings based on the sampling of fish larvae and mesozooplankton. Surveys were carried out during 2 monsoon periods in March and August 1996, using 3 cross-bathymetric transects extending to the deeper part of the shelf slope of the Andaman Sea. Station distances were either 5 or $10 \mathrm{n}$ miles apart, and at each station a series of net tows were carried out, targeting different size ranges of organisms. Plankton were identified to order (invertebrates) or family (fish larvae), and their abundances and biomass estimated. The abundance of both mesozooplankton and fish larvae peaked mid-shelf (50 to $65 \mathrm{~m}$ bottom depth) coinciding with a hydrographic front generated where the pycnocline meets the sea-bottom. An internal wave of pronounced amplitude interacts with the shelf slope at ca. $300 \mathrm{~m}$ bottom depth, and findings indicated another zone of enhanced abundance in this area. Analysis of the relative abundances of fish larvae within families revealed a marked cross-shelf structuring into a number of larval assemblages. Distinct assemblages were identified in nearshore areas, at midshelf in the area of the hydrographic front, and off the shelf break in oceanic water. Less pronounced variation was seen in the along-shelf direction and between monsoon periods.
\end{abstract}

KEY WORDS: Fish larval assemblages · Cross-shelf plankton distribution · Frontal hydrography · Monsoon periods

Resale or republication not permitted without written consent of the publisher

\section{INTRODUCTION}

There is growing evidence of strong physicalbiological linkages in marine plankton ecosystems, supported by, for example, the observed trophodynamic variability across hydrographic interfaces such as pycnoclines and fronts (LeFevre 1986, Fortier et al. 1992, Nielsen \& Munk 1998). Most of the available information on plankton dynamics and physical-biological linkages originates from studies in temperate waters, which are characterized by strong winter/ summer seasonality in heat influx and water stratifica- 
tion, while fewer studies have been carried out in tropical waters, where hydrographical conditions are different. One characteristic feature of the tropical seas is the strong, permanent temperature stratification of the water column. This is based on the permanent, conspicuous heating of the surface water, and the inflow of a cold subsurface water mass formed outside the tropic region, principally by sinking of water near the subtropical convergence. Wind-induced turbulence mixes heat down from the surface to a specific depth, and a sharp thermocline is established in the depth range of 30 to $50 \mathrm{~m}$. Another characteristic of the tropical seas (from west Africa to SE Asia) is the monsoon seasonality, driven by the twice-yearly passage of the atmospheric inter-tropical convergence zone across the equator. This passage leads to wet/dry seasonality at the coast, dry when the wind blows from the continent, and wet when strong winds blow oceanic air towards the coast. The monsoon periods influence water circulation, and can lead to flow reversal and upward transport of nutrients (Longhurst \& Pauly 1987).

The monsoon seasonality is likely to exert a strong influence on the tropical shelf ecosystem. However, it has proven difficult to single out the specific linkages between hydrography and plankton dynamics. Physicalbiological coupling is apparent in some studies, while other studies are indecisive. Madhupratap et al. (1996) and Roman et al. (2000) studied plankton in the Arabian Sea, and neither of these studies were able to distinguish any monsoon effect on the biomass variation of the zooplankton. On the contrary, Schalk (1987) and Baars et al. (1990) found indications of changes in the zooplankton in Indonesian waters that could be related to monsooninduced upwelling/downwelling processes. In the case of ichthyoplankton, seasonality in abundance estimates were indicated during a study across the Bay of Bengal (Peter 1981) and over the NW continental shelf of Australia (Young et al. 1986), while Soewito \& Schalk (1990) found only small seasonal variation in ichthyoplankton biomass in Indonesian waters.

The dissimilarities among findings and conclusions might to some extent be related to the spatial and temporal scales of the actual investigation. For example, the fine-scaled spatial variability in the hydrography of the continental shelves, especially marked in the crossshelf direction, could limit the ability to show linkages between patterns in hydrography and biology. Sampling constraints when station distances are too wide to resolve important structures were discussed by Kiøerboe et al. (1991) in their study of ichthyoplankton assemblages over the shelf area of the Andaman coast of Thailand. These authors suspected that the used cross-shelf sampling distance (10 to $15 \mathrm{~nm}$ ) was too coarse to detect significant patterns in hydrography and plankton distribution. Nevertheless, the findings from this study (Kiørboe et al. 1991) and other studies in the area, e.g. Wium-Andersen (1977) and Janekarn \& Hylleberg (1989), suggest that monsoonal activity influences hydrography and biological productivity of the shelf area.

To improve the understanding of the pelagic ecosystem of the shelf of the Andaman coast and its importance as a fisheries resources, a Thai-Danish scientific research programme was set up for the period 1996 to 2001. The overall programme was directed at studying the physical, chemical and biological linkages at the tropical shelf. We studied plankton community structures and productivity of the shelf and shelf slope in the western part of the Andaman Sea, which is a large basin situated in the eastern part of the Indian Ocean. The basin is enclosed by Peninsula Malayan in the east, and the archipelago of the Andaman and Nicobar Islands in the west. Between the Nicobar Islands strong tidal activity leads to production of largeamplitude internal waves, which propagate across the basin towards the shelf in the western part of the basin (Osborne \& Burch 1980). Our study was carried out in the area from the nearshore areas, which are characterized by mangroves and influenced by river-outflow, and across the 40 to $90 \mathrm{~km}$ wide shelf. Further offshore the sampling passed the shelf break and entered the deeper areas of more than $400 \mathrm{~m}$ water depth.

Our goals were (1) to outline the spatio-temporal variation in abundance and production of plankton at all trophic levels; (2) to identify the physical phenomena of primary importance; and (3) to investigate potential linkages between physics and plankton biology. Special emphasis was placed on monsoonal seasonality and fine-scale cross-shelf variation. Here we report on distributional patterns and assemblage structures of the mesozooplankton and fish larvae, and their relationship to hydrography. A companion paper by Nielsen et al. (2004 this issue) reports on the hydrography and lower trophic level dynamics during the same field study.

\section{MATERIALS AND METHODS}

The positions of the 3 sampling transects, numbered 1 to 3 from south to north, are illustrated in Fig. 1. The shelf is ca. $30 \mathrm{~km}$ wide at Transect 1, but widens to ca. $95 \mathrm{~km}$ at Transect 3. From the shelf break, the bottom depth increases to ca. $300 \mathrm{~m}$ within less than $15 \mathrm{~km}$. At Transect 1, the bottom slopes steeply just off the coast and our first station along this transect was at $60 \mathrm{~m}$ depth, while the other transects included areas ca. $20 \mathrm{~m}$ deep. Station distances along transects were either $5 \mathrm{n}$ miles $(\sim 9 \mathrm{~km})$ or $10 \mathrm{n}$ miles $(\sim 18 \mathrm{~km})$; the $5 \mathrm{n}$ miles distances were used in areas of steep bottom slopes. 


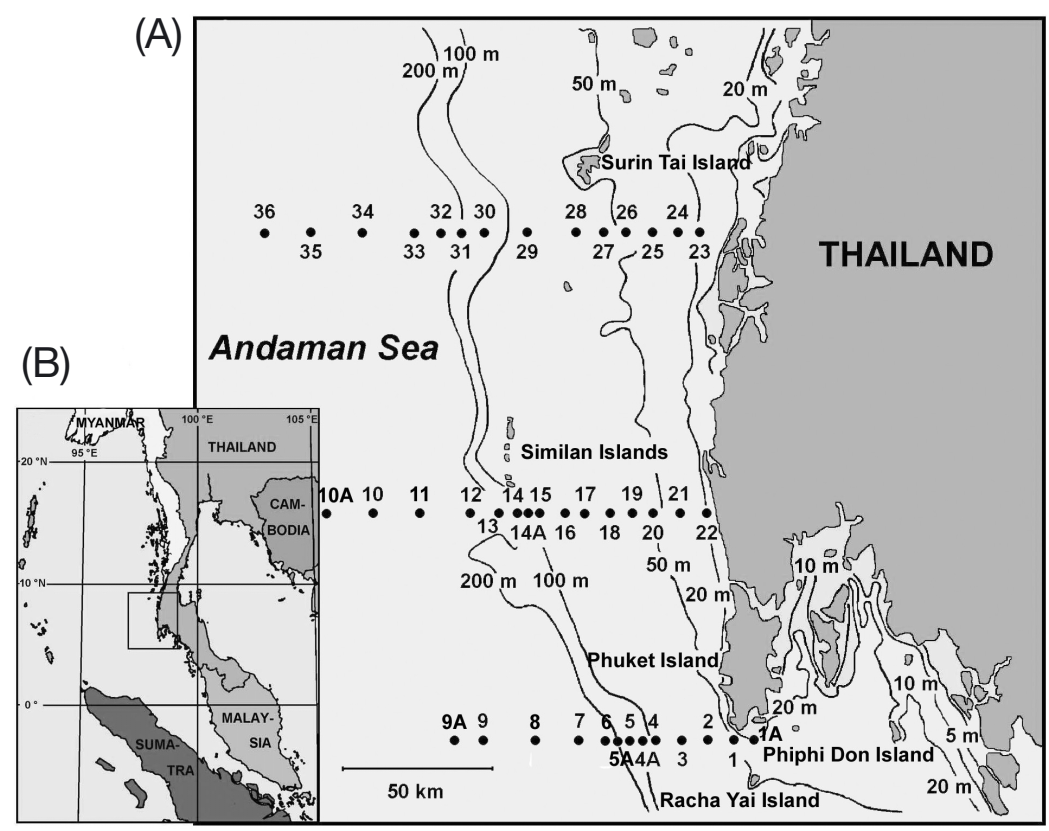

Fig. 1. (A) Study region and the Andaman Sea. (B) Area of investigation in the western part of the Andaman Sea, off the coast of Thailand. Transect sampling is indicated by lines of stations, contour lines illustrate bathymetry by isolines of 10, 20, 50, 100 and $200 \mathrm{~m}$ bottom depth

lengths and length-weight relationships of relevant groups (Satapoomin 1999), the abundances of copepods were converted to carbon weight. Further sampling of mesozooplankton was carried out by oblique hauls of a Bongo net of $500 \mu \mathrm{m}$ mesh size. This net was hauled at a ship speed of 3 knots, and lowered to $10 \mathrm{~m}$ above the bottom (maximal depth $120 \mathrm{~m}$ ) by paying/retrieving wire at speeds of $25 \mathrm{~m} \mathrm{~min}^{-1}$. The sample was preserved in $4 \%$ buffered formalin, and subsequently dried $\left(24 \mathrm{~h}\right.$ at $\left.50^{\circ} \mathrm{C}\right)$ and weighed. Carbon weight of the sample was estimated assuming a carbon content of $0.45 \mu \mathrm{g} \mathrm{C}$ $\mu \mathrm{g}$ dry $\mathrm{wt}^{-1}$ (Båmstedt 1986).

Abundance of fish larvae was estimated from sampling with a ring-net of $2 \mathrm{~m}$ diameter, equipped with a $14 \mathrm{~m}$ long net of $1000 \mu \mathrm{m}$ mesh size. Handling of the ring net was the same as described above for the Bongo net. Immediately after the haul had been carried out, fish larvae were sorted and preserved in 96\% alcohol. The remaining sample was preserved in $4 \%$ formalin, and later re-examined for overlooked larvae. All fish larvae were

Sampling was carried out during the daytime in 2 surveys. The first survey took place on 11 to 27 March 1996 during the dry NE monsoon period (NE-96), characterized by warm stable weather conditions, with predominantly northeasterly winds. The second survey was carried out on 15 to 29 August 1996, within the wet SW monsoon period (SW-96), a rainy period when strong south/southwesterly winds prevail. Due to weather conditions, only the 2 shallowest stations on Transect 3 were sampled during the SW96 cruise.

The sampling at each station was initiated by CTD profiling for description of the hydrography, and water bottle sampling for analysis of nutrients, bacteria- and protist-plankton. These findings are reported in Nielsen et al. (2004). The procedures were followed by vertically integrated hauls for mesozooplankton. A net with a mesh size of $200 \mu \mathrm{m}$ was used during both cruises, while another net of $45 \mu \mathrm{m}$ mesh-size was incorporated in the sampling programme of the second cruise (SW-96). The nets were towed from the sea bottom (or $100 \mathrm{~m}$ depth) to the surface at a speed of $12 \mathrm{~m}$ $\mathrm{min}^{-1}$. Samples were preserved in $2 \%$ buffered formalin for later enumeration of mesozooplankton groups. Copepods (copepodite stages) were the only group identified to order (Calanoida, Cyclopoida, Poecilostomatoida and Harpactocoida), and the length of their cephalothorax was measured. Based on copepod identified to family and enumerated. The length was measured (standard length, in $\mathrm{mm}$ ), and the total wet weight within family at each station was found. For weight measurement, groups of larvae were gently dried on tissue paper and weighed on a microbalance. In some cases, the weighing could not be carried out, and the weight of larval groups was estimated from larval abundance in the group and the mean weight of larvae found at a neighbour station. Based on comparative estimations of wet- and dry-weight of specimens from the family Carangidae, a conversion factor from wet- to dry-weight was calculated. Wet-weights of individual Carangidae larvae were measured after they had been lying on tissue paper for a few seconds, whereafter they were oven-dried for $24 \mathrm{~h}$ at $50^{\circ} \mathrm{C}$ and re-weighed. From these measurements we estimated a conversion factor of $0.22 \mu \mathrm{g}$ dry wt $\mu \mathrm{g}$ wet $\mathrm{wt}^{-1}$. Carbon weight of fish larvae was estimated assuming a carbon content of $0.45 \mu \mathrm{g} C \mu \mathrm{g}$ dry $\mathrm{wt}^{-1}$ (Kiørboe et al. 1987).

All estimates of plankton abundance were calculated as number per unit area $\left(\mathrm{m}^{-2}\right)$. For the vertically hauled nets, the abundance was found considering the area of the net opening only. For the oblique tows, tow length was found from calibrated flowmeters mounted in the opening of the nets, and the volume filtered was estimated from tow length and area of net opening. The estimate of abundance per unit 
area was subsequently found from plankton abundance per unit volume multiplied by the water depth (to the maximum of $120 \mathrm{~m}$ haul depth). Based on visual perception, fish larvae might react to the approaching net and escape from being caught, which would lead to an underestimation of their abundance. Hence, the daytime catchability of the ring net was evaluated by 5 comparative hauls where a daytime haul was followed by a nighttime haul (in darkness). Each pair of these hauls was carried out along the same track.

Information on larval abundances and taxonomic composition was used to cluster stations. In this analysis we used only larval families that constituted more than $1 \%$ of total abundance. Data were 4 th-root-transformed in order to lower the influence of the dominant taxa. Cluster procedures were carried out using the 'Ward' method of the programme CLUSTER in Statistical Analysis System, and cluster distances are described by semi-partial r-squared values.

\section{RESULTS}

\section{Zooplankton abundance}

The sampling by the $500 \mu \mathrm{m}$ net illustrates the variability in total biomass of all larger plankton organisms, including small fish larvae (Fig. 2a-f). This net caught plankton within a length range of ca. 1 to $5 \mathrm{~mm}$, and the biomass varied from 50 to $100 \mathrm{mg} \mathrm{C} \mathrm{m}^{-2}$ at the shallowest stations, to $300-400 \mathrm{mg} \mathrm{C} \mathrm{m}^{-2}$ at peak stations. Except for Transect 1 at NE-96, a bimodal distribution of biomass was observed along transects. The position of the shelf break is illustrated in the figure by a dotted line. A peak in the distribution of plankton biomass appears in many cases at each side of the shelf break.

Copepod biomass was estimated from sampling by the $200 \mu \mathrm{m}$ net (Fig. 2a-f). Because of the relative coarse mesh size of this net, the small harpacticoids and copepod nauplii are likely to be under-sampled a) Transect 1 NE-96

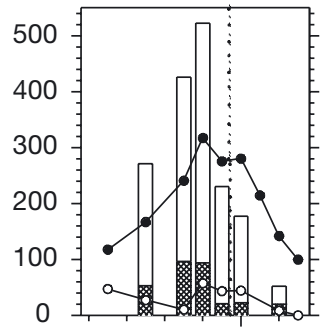

98

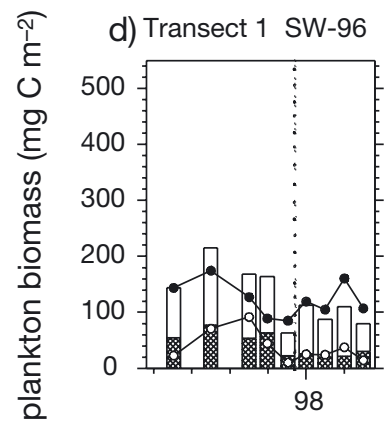

g) Transect $1 \mathrm{sW}-96$

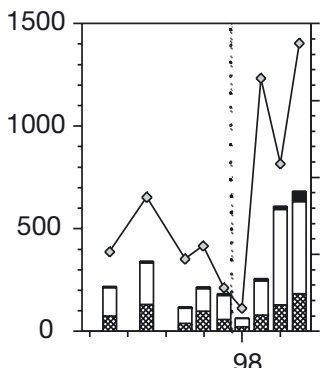

Longitude b) Transect 2 NE-96

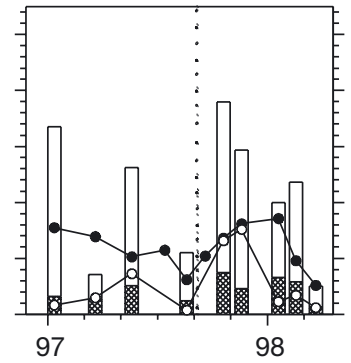

e) Transect 2 sw-96

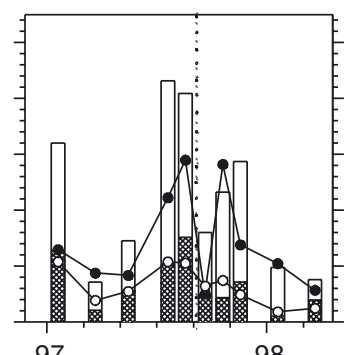

98

h) Transect 2 SW-96

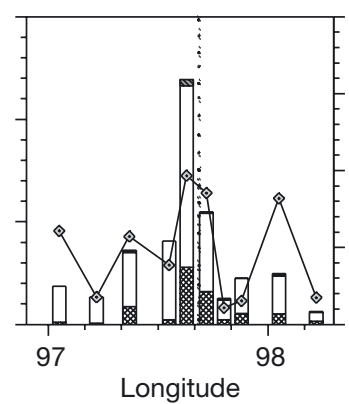

C) Transect 3 NE-96

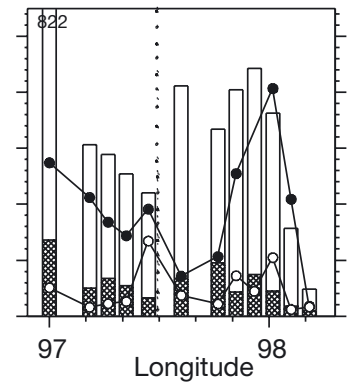

f) Transect 3 SW-96

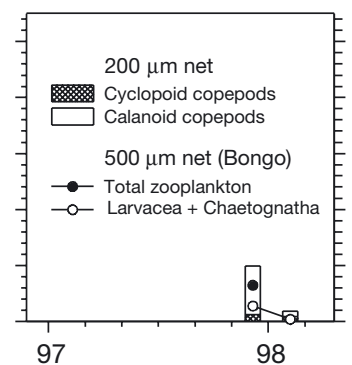

i) Transect 3 sw-96

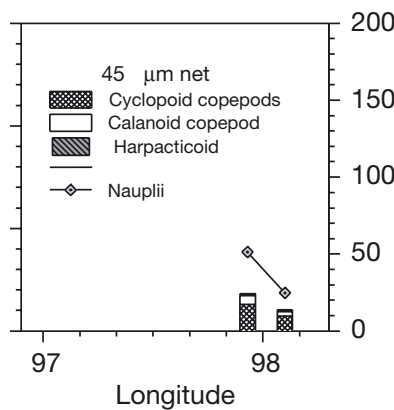

Fig. 2. (a-f) Zooplankton biomass $\left(\mathrm{mg} \mathrm{C} \mathrm{m}^{-2}\right.$ ) from the 500 and $200 \mu \mathrm{m}$ net sampling. Each graph illustrates 1 sampling sequence, the upper series is from sampling in March 1996 (NE-96), the lower series is from $\mathrm{Au}$ gust 1996 (SW-96). Only 2 stations were sampled along Transect 3 in August. Symbols and patterns used for both series are indicated in (f). (g-i) Zooplankton biomass (mg C $\mathrm{m}^{-2}$ ) from the $45 \mu \mathrm{m}$ net. Each graph illustrates a sampling sequence from August 1996 (SW-96). Symbols and patterns are indicated in (i). Vertical dotted lines in all graphs of the figure indicate the position where bottom depth reaches $100 \mathrm{~m}$, in vicinity of the shelf break. The coast is to the right in the graphs 
(Satapoomin et al. 2004 this issue), and these are not included. The length range of organisms was 0.3 to $1 \mathrm{~mm}$. Calanoid copepods dominated, with a biomass that was 3 to 4 times that of smaller cyclopoid and poecilostomatoid copepods. The estimated total biomass of copepods is significantly related to the biomass estimate of larger zooplankton caught by the $500 \mu \mathrm{m}$ net (ANOVA, $\mathrm{n}=47, \mathrm{p}<0.001$ ). While not as evident as for the $500 \mu \mathrm{m}$ net, this measure of copepod biomass also shows a tendency of a decline in biomass at the upper shelf slope. When we compare estimates from the same stations during the 2 seasons, we find no significant tendency of higher biomass in one of the seasons (ANOVA, $\mathrm{n}=38, \mathrm{p}>$ $0.5)$. The biomass was higher along Transect 1 during survey NE-96 compared to SW-96, while the opposite was the case for Transect 2. However, the relative magnitude of calanoid biomass differed significantly among stations (ANOVA, $\mathrm{n}=38, \mathrm{p}<$ $0.02)$; it was 4.6 and 2.8 times the cyclopoid/poecilostomatoid biomass in the NE-96 and SW-96, respectively. By number, calanoid copepodites contributed $60 \%$ more than the cyclopoid/poecilostomatoid during both seasons, hence, the difference was due to increased mean weight of the calanoid copepodites. The $45 \mu \mathrm{m}$ net caught all small stages of copepods, and consequently the total biomass estimate of copepods was much higher than the one based on the $200 \mu \mathrm{m}$ net; differences were evident especially at the inshore station (Fig. 2g-i). Tendencies in cross-shelf variation are, however, withheld, and the estimates from the 2 nets are weakly, but significantly, correlated $\left(\mathrm{n}=20, \mathrm{r}^{2}=0.21, \mathrm{p}<0.05\right)$. The cross-shelf distribution of the 2 important noncopepod zoo-plankters, the larvaceans and the chaetognats, resemble the distribution of the copepods (Fig. 2a-f).

In order to assess spatial variability in size composition of the copepod community and the prey availability to fish larvae, we constructed biomass spectra (Sheldon et al. 1972) of the copepods sampled with the $45 \mu \mathrm{m}$ net in the SW-96. Biomasses of copepods were accumulated in log-scaled length intervals, and the spectra were calculated for Transects 1 and 2, either inshore or offshore of the shelf break (Fig. 3). We found a marked increase in accumulated biomass in these intervals, from the smallest copepod sizes to a maximum at approx. $500 \mu \mathrm{m}$ size. The biomass of copepods was generally higher inshore, but there were no obvious differences in spectra between areas or seasons. The range of maximal preferred prey sizes, estimated for dominant fish species from the larval fish community in the area (Østergaard et al. 2004), encompasses major peaks in the spectra (range shown in Fig. 3).

\section{Fish larval abundance}

Fish larval abundance and biomass is based on daytime catches by the $2 \mathrm{~m}$ ring net. Because of the relatively large mesh size of $1000 \mu \mathrm{m}$, this net under-sampled the smallest larvae. Comparison to the sampling by the $500 \mu \mathrm{m}$ Bongo net showed an under-sampling by the ring net of larvae smaller than $5 \mathrm{~mm}$, while the ring net showed a relatively better catch-ability for larvae above $5 \mathrm{~mm}$ long. However, the comparative day/night sampling showed that the daytime catch-ability of the ringnet was reduced, probably due to gear avoidance by the larvae. Based on 5 pairs of hauls carried out both in daylight and in darkness at the same position, conversion factors were calculated for dominant taxa. No systematic differences in conversion factors were evident between taxa, and the overall catch-ability, estimated to be $340 \%$ higher at night, was used in a conversion of the daytime estimates of abundance. Estimates of larval abundance varied along transects, and were relatively higher along Transect 1 than along the other transects (Fig. 4). Larvae showed 1 or more modes in abundance along transects, with a tendency of increased abundance at each side of the shelf slope. In addition, the relative abundance of dominant families varied along the transects (Fig. 4). In the off-shelf areas of Transects 1 and 2, the larval biomass was markedly higher in the NE-96 survey than in the SW-96 survey, corresponding to higher mean weights of larvae in these areas (Fig. 5). Larval biomass estimates correlated significantly to the total zooplankton biomass estimates from the Bongo net sampling (ANOVA, $\mathrm{n}=47$, $\mathrm{r}^{2}=0.31, \mathrm{p}<0.0001$ ), while the relationship with estimates from the vertical zooplankton tows was poor (ANOVA, $\mathrm{n}=47, \mathrm{r}^{2}=0.09, \mathrm{p}<0.04$ ).

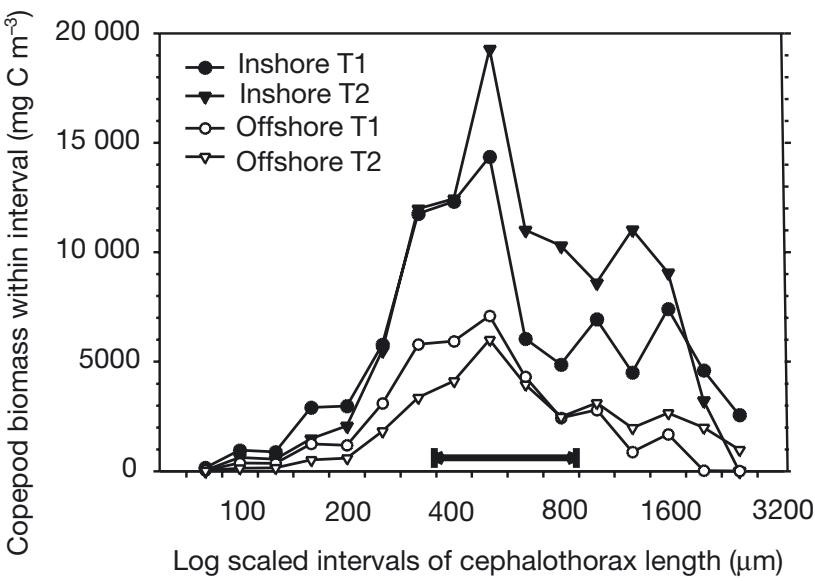

Fig. 3. Biomass spectra of the copepods caught by the $45 \mu \mathrm{m}$ net during SW-96. Copepod biomass $\left(\mathrm{mg} \mathrm{C} \mathrm{m}^{-3}\right)$ integrated within log-scaled cephalothorax length intervals $(\mu \mathrm{m})$. Curves shown for inshore and offshore sections of Transects 1 and 2 as indicated by inserted legend. Inserted range of copepod lengths indicates preferred prey sizes of abundant fish larvae 
a) Transect 1 NE-96

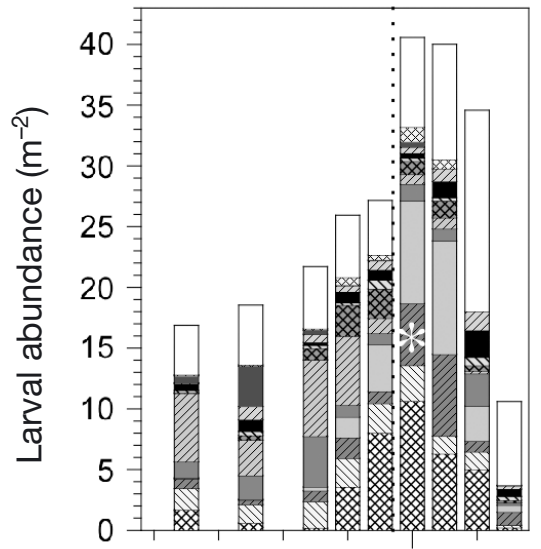

98 b) Transect 2 NE-96

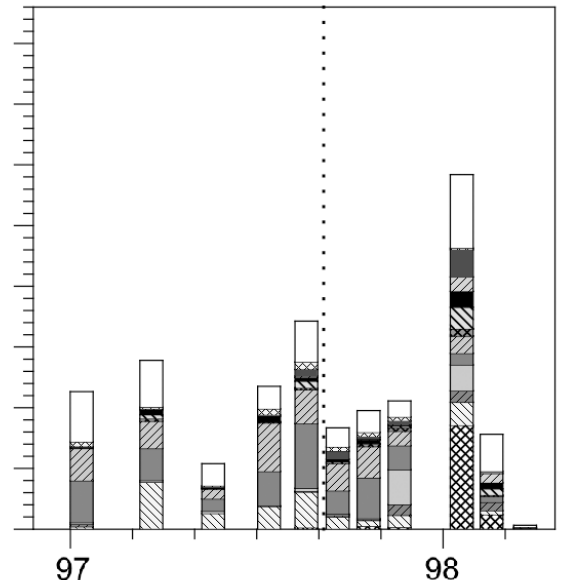

97
C) Transect 3 NE-96

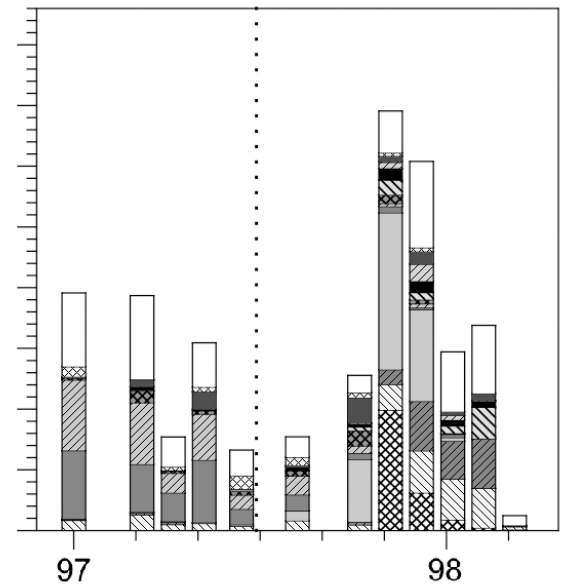

f)

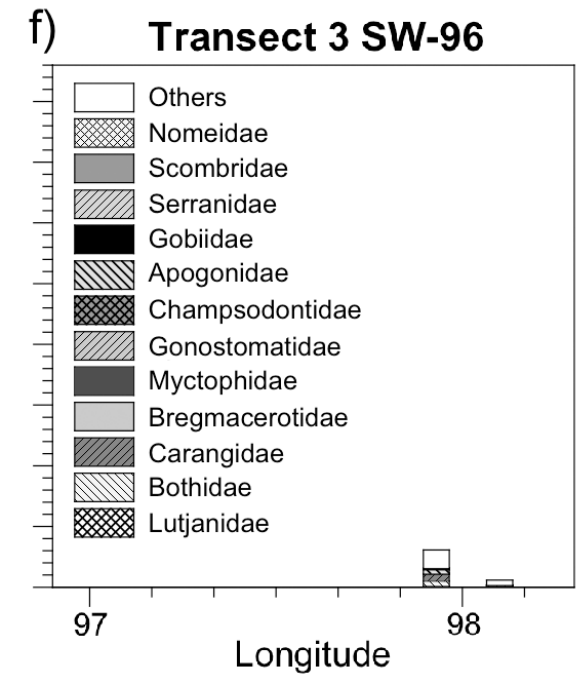

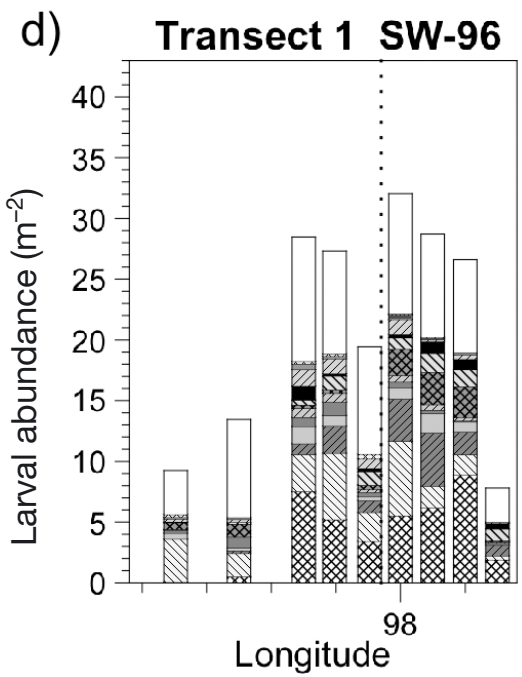

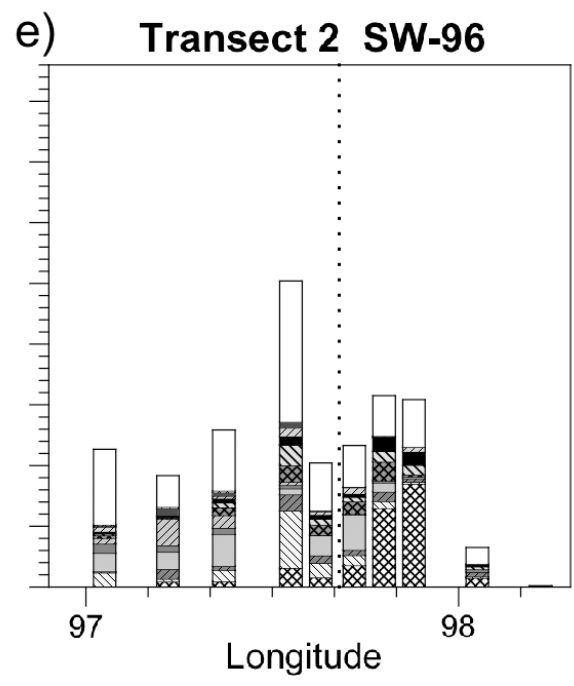

Fig. 4. (a-f) Abundance of fish larvae (no. $\mathrm{m}^{-2}$ ) along the 3 transects. Stacked bars show abundance of the 12 most abundant families, legend in (f). The catch of Carangidae at $98^{\circ} \mathrm{E}$ on Transect $1, \mathrm{NE}-96$ was extraordinarily high $\left(9.1 \mathrm{ind} . \mathrm{m}^{-2}\right)$, and bar is not shown at full size (indicated by star). Vertical dotted lines in all graphs of the figure indicate the position where bottom depth reaches $100 \mathrm{~m}$, in the vicinity of the shelf break. The coast is to the right in the graphs

\section{Distribution and taxonomic diversity of fish larvae}

We identified 109 families of which 101 and 90 were represented at the NE-96 and SW-96 surveys, respectively. In Table 1 the relative dominance among the 35 most important families is listed, showing how the relative dominance of families changes between seasons. Some families, like Bothidae, Carangidae, Bregmacerotidae and Myctophidae, dominate both in abundance and biomass, while others, like Gonostomatidae and Lutjanidae, were abundant, but of low biomass. A number of families were not considered in the integration of biomass and listing of relative dominance because these were only represented by infrequent catches of very large specimens.
There were marked taxonomic differences in distribution. Some families were predominantly distributed over the shelf, while others were found beyond the shelf break (Figs. 4 \& 5). The relative inshore/offshore position of the 35 most abundant families is indicated in Table 1. Of the most abundant, Lutjanidae, Carangidae and Apogonidae were typical shelf inhabitants, while Bregmacerotidae, Myctophidae and Nomeidae were mostly found beyond the shelf break. The distributional patterns for the families Myctopidae and Lutjanidae exemplify the marked difference between taxa, and the significant peaks in occurrence of single families (Fig. 6).

Fish larval assemblages were analyzed further by cluster analysis. All sampled stations, covering sea- 
sons, transects and positions along transects, were clustered based on corresponding estimates of fish larval abundances and taxonomic composition (Fig. 7). In the dendogram the primary separation takes place between inshore and offshore assemblages, and inshore of the shelf break there is a further distinction between nearshore and shelf assemblages. In the shelf area, the analysis discriminates between the 2 cruises, and at a lower level the stations cluster according to transects. Offshore of the shelf break, the outermost stations of the SW-96 cruise are clustered together, while stations of the NE-96 are separated into outermost and transitionary sections. In conclusion, the spatial cross-shelf structuring of taxonomic composition is by far the most important; at the shelf this overrides both seasonal and along-shelf effects, while for the shelf slope sections the seasonal effects override further spatial clustering.

\section{DISCUSSION}

The present study showed characteristic patterns in both the meso- and ichthyoplankton distributions on the shelf areas in the Andaman Sea. Distinct plankton assemblages were apparent along the northern-most transect, which crosses a relatively wide shelf. Our ability to distinguish cross-shelf changes in plankton abundance/composition was more restricted on the other transects where the changes happened over shorter distances, apparently due to the narrow shelf. However, most of our data pointed to enhanced abundances at 2 sites: either inshore of the shelf break in a bottom depth range of 60 to $80 \mathrm{~m}$, or offshore, at the shelf slope in a bottom depth range of 250 to $350 \mathrm{~m}$. Accordingly, our physical measurements carried out in parallel with the biological sampling revealed characteristic hydrographical patterns inshore and offshore of a) Transect 1 NE-96

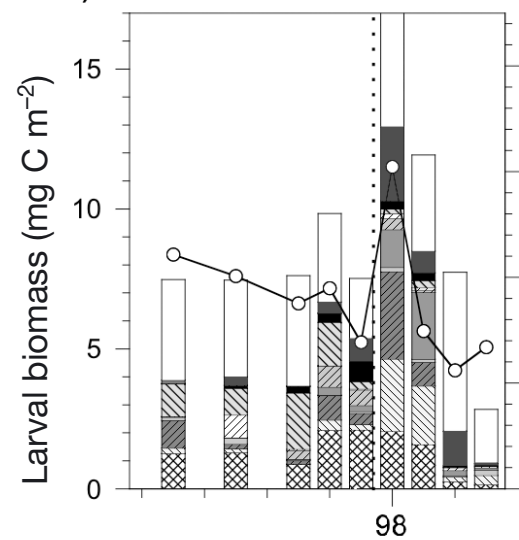

d) Transect $1 \mathrm{sw}-96$

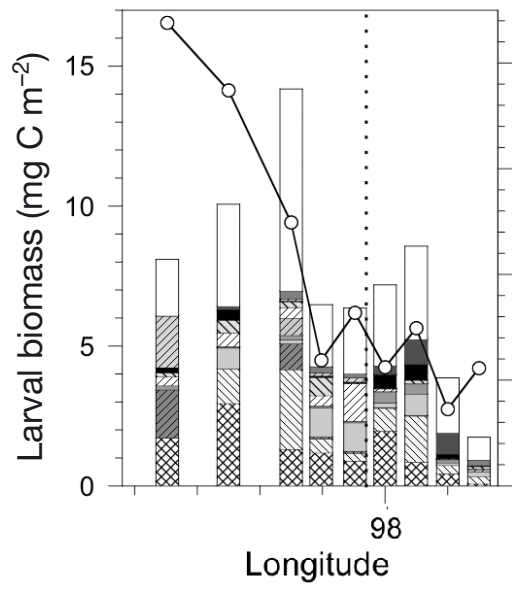

b)

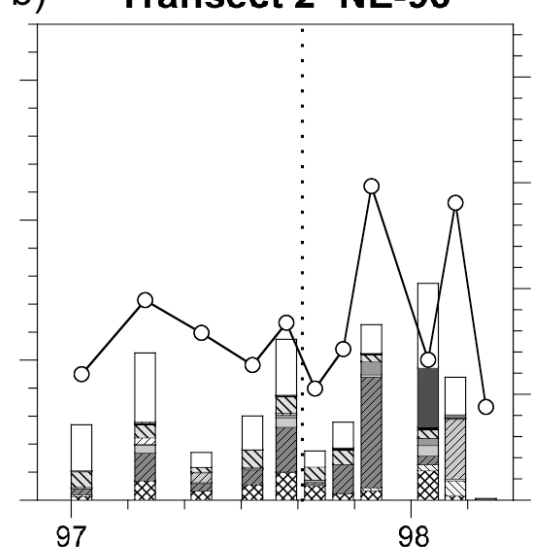

e) Transect 2 sW-96

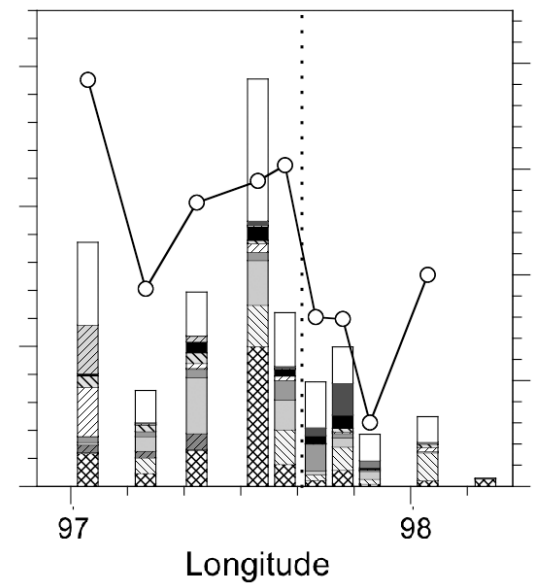

C) Transect 3 NE-96

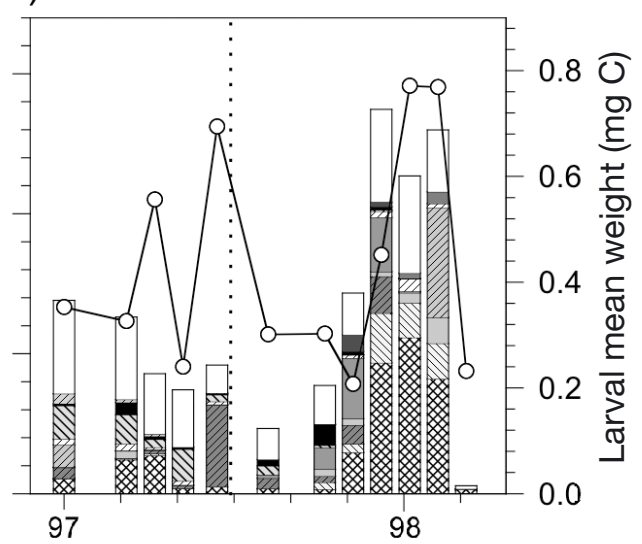

f) Transect 3 SW-96

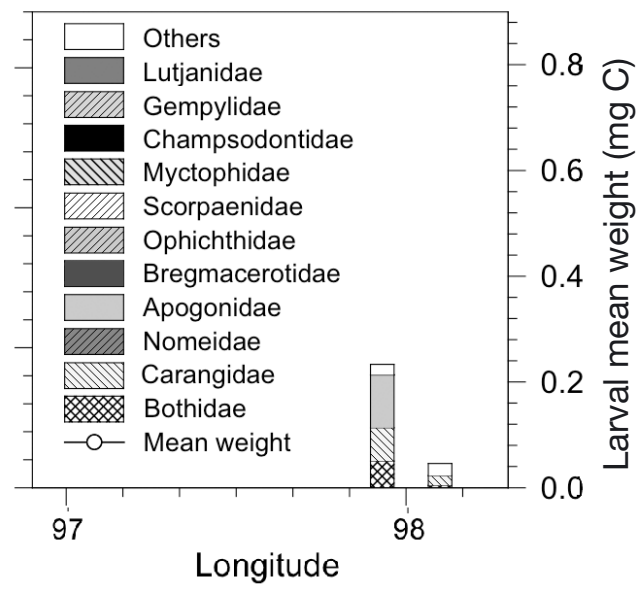

Fig. 5. (a-f) Larval biomass and mean weight along the 3 transects. Larval mean weight (mg C ind. ${ }^{-1}$ ) is illustrated by open circles connected by full lines, corresponding to right axis. Stacked bars show abundance of the 11 families dominating in biomass, legend in (f). Vertical dotted lines in all graphs of the figure indicate the position where bottom depth reaches $100 \mathrm{~m}$, in vicinity of the shelf break. The coast is to the right in the graphs 
Table 1. Dominance and distributional characteristics of major fish families. Determined centre of distribution is indicated by: I = nearshore, Ix = mid-shelf, $\mathrm{O}=$ outer shelf, $\mathrm{Ox}=$ off the shelf break

\begin{tabular}{|c|c|c|c|c|c|}
\hline \multirow[t]{3}{*}{ Family } & \multicolumn{4}{|c|}{$\begin{array}{c}\text { Dominance of family } \\
\text { (\% of total abundance })\end{array}$} & \multirow{3}{*}{$\begin{array}{c}\text { Centre of } \\
\text { distribution } \\
\text { March and } \\
\text { August }\end{array}$} \\
\hline & \multicolumn{2}{|c|}{ Density } & \multicolumn{2}{|c|}{ Biomass } & \\
\hline & March & August & March & August & \\
\hline Bothidae & 8.4 & 11.8 & 26.3 & 19.9 & $\mathrm{IO}$ \\
\hline Carangidae & 10.6 & 6.6 & 3.5 & 13.7 & I \\
\hline Lutjanidae & 10.6 & 19.2 & 1.7 & 2.5 & I \\
\hline Bregmacerotidae & 10.5 & 5.9 & 5.4 & 3.3 & $\mathrm{O}$ \\
\hline Myctophidae & 11.1 & 2.2 & 3.8 & 1.9 & $O x$ \\
\hline Apogonidae & 2.1 & 4.2 & 2.5 & 9.7 & I \\
\hline Nomeidae & 1.8 & 0.5 & 11.2 & 3.9 & $\mathrm{O}$ \\
\hline Gonostomatidae & 10.4 & 2.3 & 1.1 & 1.0 & $\mathrm{Ox}$ \\
\hline Champsodontidae & 2.7 & 5.1 & 2.3 & 3.3 & $\mathrm{Ix}$ \\
\hline Gobiidae & 2.7 & 2.8 & 2.3 & 1.8 & $\mathrm{I}$ \\
\hline Scorpaenidae & 0.7 & 2.2 & 1.6 & 4.6 & Ix \\
\hline Serranidae & 2.0 & 2.8 & 2.4 & 1.5 & $\mathrm{IO}$ \\
\hline Kyphosidae & 0.5 & 0.2 & 6.8 & 0.4 & $\mathrm{O}$ \\
\hline Ophichthidae & 0.2 & 0.2 & 5.9 & 0.9 & $\mathrm{I}$ \\
\hline Callionymidae & 1.6 & 0.8 & 3.0 & 1.1 & $\mathrm{O}$ \\
\hline Gempylidae & 0.8 & 0.9 & 0.4 & 3.9 & Ox \\
\hline Dactylopteridae & 0.5 & 2.3 & 0.5 & 2.6 & $\mathrm{O}$ \\
\hline Scombridae & 2.8 & 1.0 & 0.7 & 1.3 & $\mathrm{IO}$ \\
\hline Pleuronectidae & 0.2 & 1.9 & 0.5 & 2.6 & $\mathrm{O}$ \\
\hline Percophidae & 1.4 & 1.2 & 1.5 & 0.7 & $\mathrm{Ix}$ \\
\hline Cepolidae & 0.4 & 0.9 & 0.4 & 2.6 & $\mathrm{I}$ \\
\hline Percichthyidae & 0.1 & 1.8 & 0.0 & 1.8 & $\mathrm{O}$ \\
\hline Xenocongridae & 0.1 & 0.4 & 3.2 & 0.2 & $\mathrm{O}$ \\
\hline Lethrinidae & 0.3 & 1.7 & 0.2 & 1.0 & I \\
\hline Balistidae & 0.1 & 0.7 & 0.0 & 2.3 & $\mathrm{O}$ \\
\hline Paralepididae & 0.8 & 0.7 & 1.0 & 0.5 & $\mathrm{O}$ \\
\hline Priacanthidae & 1.5 & 1.6 & 0.0 & 0.0 & $\mathrm{I}$ \\
\hline Trichiuridae & 0.3 & 1.3 & 0.2 & 1.2 & I \\
\hline Leiognathidae & 0.8 & 1.1 & 0.2 & 0.8 & $\mathrm{I}$ \\
\hline Acanthuridae & 0.3 & 1.9 & 0.0 & 0.6 & $\mathrm{O}$ \\
\hline Cynoglossidae & 0.7 & 0.6 & 0.7 & 0.6 & $\mathrm{I}$ \\
\hline Monacanthidae & 1.4 & 1.1 & 0.0 & 0.0 & $\mathrm{I}$ \\
\hline Engraulidae & 1.3 & 0.3 & 0.6 & 0.1 & $\mathrm{I}$ \\
\hline Nemichthyidae & 0.7 & 1.2 & 0.0 & 0.0 & I \\
\hline Platycephalidae & 0.4 & 0.6 & 0.3 & 0.6 & $\mathrm{I}$ \\
\hline
\end{tabular}

characteristics and the present observations of zooplankton abundance. In a statistical test, which incorporated the along-shelf (i.e. transect) variability, the relationship between hydrography (expressed by the variation in salinity at $10 \mathrm{~m}$ depth) and plankton abundance was insignificant for the smaller plankton caught by the vertically hauled net (ANOVA, $\mathrm{n}=42, \mathrm{p}>0.86$ ), whilst the effect was significant for the larger zooplankton from the Bongo net, and for the fish larvae from the ring net (both in number and biomass) (ANOVA, for all: $n=46, p<0.05$ ).

The differences between the estimates of zooplankton abundance, based either on vertical towed nets or on Bongo nets, might not only stem from the differences between mesh sizes. The oblique tows of the Bongo nets integrate a larger water mass and thus are less sensitive to small-scale horizontal patchiness than the vertically hauled nets. In a comparative study of the variability of vertical net-derived zooplankton abundance, Satapoomin et al. (2004) compared twelve $200 \mu \mathrm{m}$ net tows, laid out at $500 \mathrm{~m}$ distances in the vicinity of our Transect 2 . This sampling revealed biomass estimates ranging from 521 to $1710 \mathrm{mg} \mathrm{C} \mathrm{m}^{-2}$ with a CV of 0.39 . Thus, substantial variability is to be found at scales smaller than the present 9 to $18 \mathrm{~km}$ scale of sampling.

The copepod biomass estimates from the $45 \mu \mathrm{m}$ net sampling, which included nauplii as well as smaller copepodites and adults, was ca. $80 \%$ higher than

the shelf break (Nielsen et al. 2004). On the shelf, the water is mixed inshore of the region where the strong pycnocline meets the bottom. Hence, a frontal zone is established in this area, which is apparent from declining isopycnals observed in areas where bottom depths are 55 to $65 \mathrm{~m}$. The other prominent hydrographic feature observed during the study was the oscillations of the pycnocline at the shelf slope. Apparently, an internal wave is amplified when the bottom is of a certain depth-range, and this feature was seen in areas of 250 to $350 \mathrm{~m}$ bottom depth. Both the frontal zone and the internal wave oscillations induced upward transport of deeper water, detectable by increased salinity in the surface waters and an associated increase in phytoplankton (Nielsen et al. 2004). Accordingly, there is an apparent relationship between these hydrographical those obtained from the other nets. Estimates reached 800 to $1200 \mathrm{mg} \mathrm{C} \mathrm{m}^{-2}$ offshelf, while peak values on the shelf were ca. 400 to $600 \mathrm{mg} \mathrm{C} \mathrm{m}^{-2}$. While the distribution of copepods on each transect differed between seasons, there was no significant tendency of higher biomass in one of the seasons. This lack of a clear seasonal signal in biomass of the copepods is in accordance with comparable findings for lower trophic levels (Nielsen et al. 2004). Similarly, seasonal changes in copepod communities have not been detectable during studies in other areas, e.g. in the NE Arabian Sea (Madhupratap et al. 1996).

Our observations of characteristic cross-shelf patterns in fish larval abundance confirm earlier observations in the area of a mid-shelf assemblage of high abundance (Janekarn \& Kiørboe 1991, Kiørboe et al. 1991), and the 
a) Transect 1 NE-96

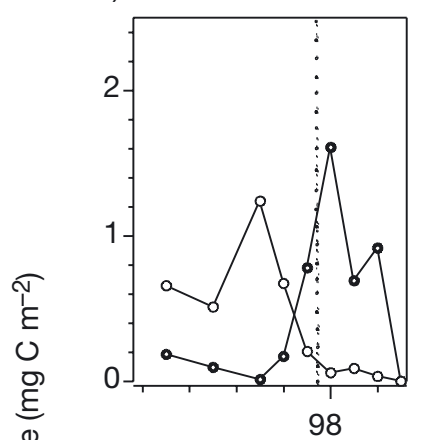

d) Transect $1 \mathrm{SW}-96$

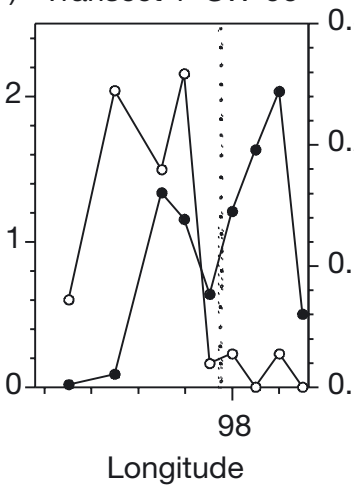

b)

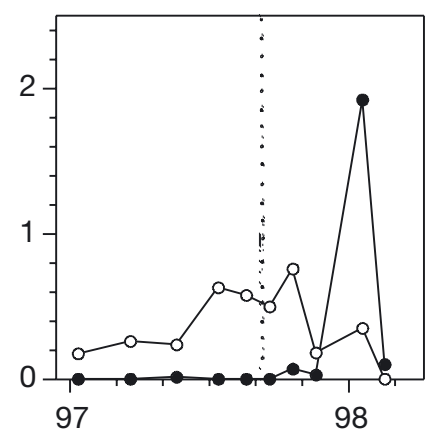

e) Transect 2 SW-96 c) Transect $3 \mathrm{NE}-96$

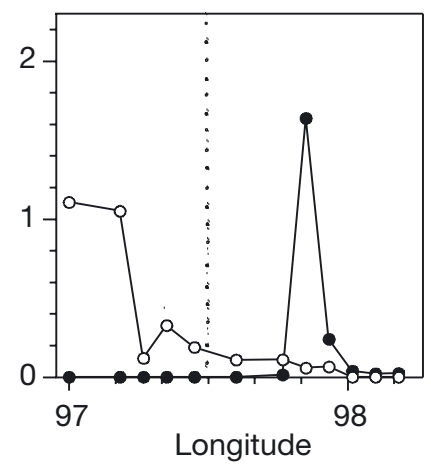

0.15

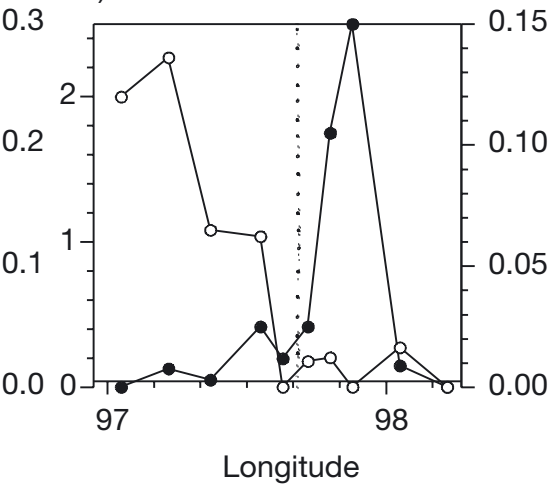

Fig. 6. (a-e) Variation in abundance of the Lutjanidae and Myctophidae families along the 3 transects. Filled circles illustrate the abundance of Lutjanidae (no. $\mathrm{m}^{-2}$ ), corresponding to left axes in $(\mathrm{a}-\mathrm{e})$. Open circles illustrate the abundance of Myctophidae (no. $\mathrm{m}^{-2}$ ), corresponding to left axes in $(\mathrm{a}-\mathrm{c})$ and right axes in $(\mathrm{d}-\mathrm{e})$. Vertical dotted lines in all graphs of the figure indicate the position where bottom depth reaches $100 \mathrm{~m}$, in vicinity of the shelf break. The coast is to the right in the graphs

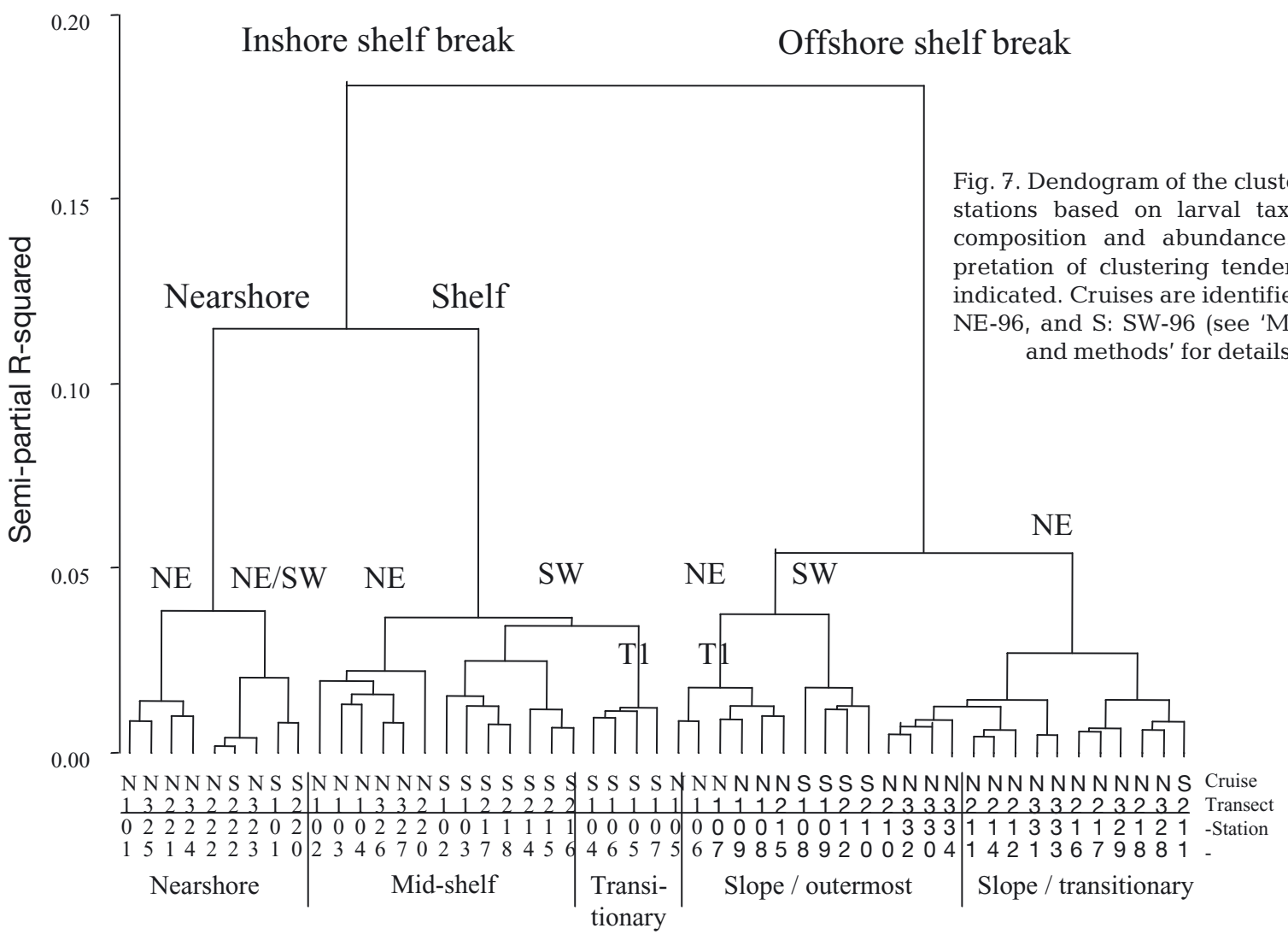


findings of an additional off-shelf assemblage corresponds to observations by Young et al. (1986) from another tropical shelf area. Young et al. (1986) used crossshelf transects off NW Australia to analyze seasonal and temporal distribution of larvae, and found low concentrations of larvae on the outer part of the shelf (130 to $210 \mathrm{~m}$ depth), with increasing concentrations towards the open ocean and the mid-shelf (60 to $70 \mathrm{~m}$ depth). Further inshore (to 40-50 m depth) they found another decline in larval abundance. Other studies, investigating larval fish assemblages at continental shelf areas in the tropics, have found strong cross-shelf gradients in abundance, but were unable to detect consistent patterns related to hydrography or other factors (Leis \& Goldman 1987, Williams et al. 1988, Leis 1993).

Obviously the cross-shelf abundance variability is closely connected to the variability in taxonomic composition of the larvae. In the present study, the abundance of each fish family peaked within a narrow crossshelf range. Often the majority of larvae from 1 family were caught at only 1 to 3 cross-shelf stations, i.e. within a section of only $15 \mathrm{~km}$ width. Hence, underlying the general pattern of enhancements in larval abundance mid-shelf and at the shelf slope, we find 'local' enhancements at the family level. No families peaked in abundance in the 'low abundance' area just off the shelf break, and assemblages on each side of the shelf break were clearly separated. This is also evident from the cluster analysis of family composition, which makes a distinction between these 2 assemblages at the highest significance level. At the next level, the analysis distinguishes between nearshore and mid-shelf assemblages, followed by seasonal and further cross-shelf distinction. The along-shelf effect (i.e. differences between transects) is very weak according to this analysis.

We did not sample the entire water column with the $1000 \mu \mathrm{m}$ net, but used a maximal haul depth of $120 \mathrm{~m}$ when our sampling proceeded off the shelf break. The adult stages of the dominant meso-pelagic myctophid and gonostomatid species show extensive diel migration (to depths from 50 to 600 m, Roe \& Babcock 1984), and the restricted sampling depth of the net might have biased our abundance estimates in deeper areas. However, smaller fish are distributed higher in the water column (Roe \& Babcock 1984), and a study of vertical distribution patterns of tropical fish larvae by Smith \& Suthers (1999) showed that the majority of the larvae occurred above the $100 \mathrm{~m}$ sampling depth. A study on the vertical distribution of larval myctophid species in the Arabian Sea showed that the average vertical distributions were well above $100 \mathrm{~m}$ water depth (Röpke 1993). Röpke (1993) did not find significant differences between vertical distributions during day or night; however, daytime catches were much below those obtained during the night ( $25 \%)$, in agreement with our observations. While larval fish avoidance of towed nets during daylight periods is a well-known problem, the transparency of upper water masses in the tropics apparently magnifies the problem. In order to obtain unbiased estimates of fish larval biomass, we used a set of comparative day/night hauls to evaluate and compensate for daytime avoidance. However, due to lack of sufficient information, we could not incorporate size and/or taxonomic effects in the conversion of estimates.

Our identification of dominant families and larval fish assemblages at the shelf and shelf slope of the Andaman Sea shows similarities to other observations of cross-shelf distributional patterns of larval fish families. For example the 10 dominant families in our study (contributing $65 \%$ of total abundance) are also very important off NW Australia (contributing to $38 \%$ of all catch in the study by Young et al. 1986). For example the families Carangidae, Apogonida, Gobidae, Gonostomatidae and Myctophidae are among the dominant in both studies. These 5 families are also very common in NE Australia (Leis 1993), and furthermore they are among the most abundant in areas of the tropical Atlantic, e.g. off eastern Brazil (Nonaka et al. 2000). Commonly, larval fish communities are found in specific assemblages, basically distinguished to a shelf group and an oceanic group on each side of the shelf break. Many studies subdivide these 2 basic groups, using an array of terms for identified assemblages. From shallow to deep areas the terms lagooneal/near-reef, nearshore/ coastal, mid-shelf/neritic, outer-shelf/transitionary, slope and oceanic assemblages have been used (Boehlert \& Mundy 1993, Leis 1993, Richards et al. 1993, Sanvincente-Añorve et al. 2000). In our study, the cross-shelf effect is conspicuous, overruling the seasonal and along-shelf effects, and we distinguish between nearshore, mid-shelf, transitionary and shelf slope assemblages. Each assemblage includes a number of characteristic families which are described for comparable zones in other studies, and which often coincide with known spawning areas of the adults (Grothues \& Cowen 1999). Species of the Bothidae, Gobidae and Apogonidae were common in the coastal areas, while the Carangidae and Lutjanidae were predominantly distributed further offshore. The Bregmacerotidae and Nomeidae were seen at the outer-shelf, and finally the Myctophidae and Gono-stomatidae were characteristic members of the oceanic group. These observations are consistent with reported distribution patterns from studies by, e.g., Leis (1993), Richards et al. (1993) and Smith \& Suthers (1999).

As noted above, findings of enhanced zoo- and ichthyoplankton abundances coincided with specific hydrographical features (frontal zone formation at mid-shelf and internal wave oscillations off the shelf break). While the primary producers also showed link- 
ages to hydrography, we expected to see the pattern reflected for other (lower) components of the food web. However, Nielsen et al. (2004) did not find support for such a general tendency when investigating bacteria and protist communities in the area. Apparently, the high turnover rates of organisms at lower trophic levels restricts the accumulation of their biomass, while such accumulation can take place for the more slowly growing organisms at the higher trophic levels.

Acknowledgements. We are grateful to the staff of the Phuket Marine Biological Productivity Unit (PMBC) and to the crew of RV 'Chrakratong Tongyai' for their efficient assistance during laboratory and field work. This work is supported by the Department of Fisheries (Thailand), the Danish Institute for Fisheries Research, and by a DANIDA grant (\#104.P.3).

\section{LITERATURE CITED}

Baars MA, Sutumo AB, Oosterhuis SS, Arinardi OH (1990) Zooplankton abundance in the eastern Banda Sea and northern Arafura Sea during and after the upwelling season, August 1984 and February 1985. Neth J Sea Res 25(4):527-543

Båmstedt U (1986) Chemical composition and energy content. In: Corner EDS, O'Hara SCM (eds) The biological chemistry of marine copepods. Clarendon Press, Oxford, p 1-58

Boehlert GW, Mundy BC (1993) Ichthyoplankton assemblages at seamounts and oceanic islands. Bull Mar Sci 53(2):336-361

Fortier L, Levasseur ME, Drolet R, Therriault JC (1992) Export production and the distribution of fish larvae and their prey in a coastal jet frontal region. Mar Ecol Prog Ser 85: 203-218

Grothues TM, Cowen RK (1999) Larval fish assemblages and water mass history in a major faunal transition zone. Cont Shelf Res 19:1171-1198

Janekarn V, Hylleberg J (1989) Coastal and offshore primary production along the west coast of Thailand (Andaman Sea) with notes on physical-chemical variables. Phuket Mar Biol Cent Res Bull 51

Janekarn V, Kiørboe T (1991) The distribution of fish larvae along the Andaman coast of Thailand. Phuket Mar Biol Cent Res Bull 56:41-61

Kiørboe T, Munk P, Richardson K (1987) Respiration and growth of larval herring Clupea harengus: relation between specific dynamic action and growth efficiency. Mar Ecol Prog Ser 40:1-10

Kiørboe T, Janekarn V, Poung-In S, Sawangarreruks S, Phukhao P (1991) New fisheries resources in the Andaman Sea: indirect oceanographic evidence. Thai Fish Gaz 44(3):261-270

LeFevre J (1986) Aspects of the biology of frontal systems. Adv Mar Biol 23:264-281

Leis JM (1993) Larval fish assemblages near Indo-Pacific coral reefs. Bull Mar Sci 53(2):362-392

Leis JM, Goldman B (1987) Composition and distribution of larval fish assemblages in the Great Barrier Reef Lagoon near Lizard Island, Australia. Aust J Mar Freshw Res 38: 211-233

Longhurst AR, Pauly D (1987) Ecology of tropical oceans. Academic Press, London

Madhupratap M, Kumar SP, Bhattathiri PMA, Kumar MD, Raghukumar S, Nair KKC, Ramaiah N (1996) Mechanism of the biological response to winter cooling in the northeastern Arabian Sea. Nature 384(6609):549-552

Nielsen TG, Munk P (1998) Zooplankton diversity and the predatory impact by larval and small juvenile fish at the Fisher Banks in the North Sea. J Plankton Res 20(12): 2313-2332

Nielsen TG, Bjørnsen PK, Boonruang P, Fryd M and 9 others (2004) Hydrography, bacteria and protist communities across the continental shelf and shelf slope of the Andaman Sea (NE Indian Ocean). Mar Ecol Prog Ser 274:69-86

Nonaka RH, Matsuura Y, Suzuki K (2000) Seasonal variation in larval fish assemblages in relation to oceanographic conditions in the Abrolhos Bank region off eastern Brazil. Fish Bull 98:767-784

Osborne AR, Burch TI (1980) Internal solitons in the Andaman Sea. Science 208:451-460

Østergaard P, Munk P, Janekarn V (2004) Contrasting feeding patterns among species of fish larvae from the tropical Andaman Sea. Mar Biol (in press)

Peter KJ (1981) Influence of environmental changes on the distribution of ichthyoplankton in the Bay of Bengal. Rapp P-v Réun Cons Int Explor Mer 178:210-216

Richards WJ, McGowan MF, Leming T, Lamkin JT, Kelley S (1993) Larval fish assemblages at the loop current boundary in the Gulf of Mexico. Bull Mar Sci 53(2):475-537

Roe HSJ, Babcock J (1984) The diel migrations and distributions within a mesopelagic community in the north-east Atlantic. 5. Vertical migration and feeding of fish. Proc Oceanogr 13:389-424

Roman M, Smith S, Wishner K, Zhang X, Gowing M (2000) Mesozooplankton production and grazing in the Arabian Sea. Deep Sea Res II 47(7-8):1423-1450

Röpke A (1993) Do larvae of mesopelagic fishes in the Arabian Sea adjust their vertical distribution to physical and biological gradients? Mar Ecol Prog Ser 101:223-235

Sanvincente-Añorve L, Flores-Coto C, Chiappa-Carrara X (2000) Temporal and spatial scales of ichthyoplankton distribution in the southern Gulf of Mexico. Estuar Coastal Shelf Sci 51:463-475

Satapoomin S (1999) Carbon contents of some common tropical Andaman Sea copepods. J Plankton Res 21(11):2117-2123

Satapoomin S, Nielsen TG, Hansen PJ (2004) Andaman Sea copepods: spatio-temporal variations in biomass and production, and role in the pelagic food web. Mar Ecol Prog Ser 274:99-122

Schalk PH (1987) Monsoon related changes in zooplankton biomass in the eastern Banda Sea and Anu Basin. Biol Ocean 5:1-12

Sheldon RW, Praksh A, Sutcliffe Jr WH (1972) The size distribution of particles in the ocean Limnol Oceanogr 17: $327-340$

Smith KA, Suthers IM (1999) Displacement of diverse ichthyoplankton assemblages by a coastal upwelling event on the Sydney shelf. Mar Ecol Prog Ser 176:49-62

Soewito, Schalk PH (1990) Spatial and seasonal patterns in fish larval distribution in the Banda Sea (Indonesia). Neth J Sea Res 25(4):591-600

Williams DM, Dixon P, English S (1988) Cross shelf distribution of copepods and fish larvae across the central Great Barrier Reef. Mar Biol 99:577-589

Wium-Andersen S (1977) Primary production in waters around Surin Islands off the west coast of Thailand. Phuket Mar Biol Cent Res Bull 16

Young PC, Leis JM, Hausfield HF (1986) Seasonal and spatial distribution of fish larvae in waters over the north west continental shelf of western Australia. Mar Ecol Prog Ser 31:209-222 